\title{
The effect of problem based learning model on learning outcomes in the vocational high school students
}

\author{
Lera Kurniatul Aslam*, Suparji \&Tri Rijanto \\ Department of Technology and Vocational Education, State University of Surabaya, East Java, 60231, Indonesia \\ lera.18015@mhs.unesa.ac.id; suparji@unesa.ac.id; tririjanto@unesa.ac.id \\ *Corresponding Author: lera.18015@mhs.unesa.ac.id | Phone Number: +6281249847646
}

\section{ARTICLE INFO}

Received: 27-05-2021

Received in revised: 25-06-2021

Accepted: 19-07-2021

Available online: $30-8-2021$

\section{KEYWORDS}

Problem Based Learning; Learning outcomes; Basics of; Building Construction and Soil; Measurement Techniques;

\section{A B S T R A C T}

The main problem in formal learning is that teachers carry out learning with direct learning models and lectures. The right learning model can maximize student learning outcomes and learning objectives will be achieved. This study aims to determine the effect of the Problem Based Learning (PBL) learning model on the learning outcomes of vocational high school students. This research was conducted through a literature review and relevant research results and was continued through a Focus Group Discussion (FGD). From the research it was found that there was a significant positive influence between the problem-based learning (PBL) model variable and student learning outcomes, which meant that student learning outcomes could be improved through the application of the Problem Based Learning (PBL) learning model.

\section{INTRODUCTION}

Vocational High School (SMK) is an educational institution that is responsible for creating human resources who have the ability, expertise and skills. So, vocational graduate students have readiness to enter the world of work. Vocational graduate students must have high stamina, master their skills and the basics of science and technology, have a high work ethic, and be able to communicate according to their work, and have the ability to develop themselves so they can work effectively and efficiently and develop skills and skills. Basic competencies explain the specifications, characteristics and procedures for concrete construction listed in the 2013 curriculum in the subject of construction basics of the Building Modeling and Information Design (DPIB) expertise program, which requires students to understand the material. Good understanding and mastery of the material will help students face the world of work. If the student's knowledge is minimum, it will also have an impact on the learning outcomes achieved. The main problem in formal learning is that teachers carry out learning with direct learning models and lectures. The right learning model can maximize student learning outcomes and learning objectives will be achieved. According to the Directorate General of Higher Education, the Problem Based Learning (PBL) learning mo- del is learning by utilizing problems so that students search for information so that they can solve problems. Meanwhile, according to Sanjaya (2006: 214) explains that problem based learning is a series of activities in learning that focus on the process of solving problems faced scientifically. In addition, the PBL learning model provides students with several problems so that they can carry out investigations and investigations (Arends, 2008: 41).

The Problem Based Learning (PBL) learning model is a problem-solving based learning model which consists of 5 phases, namely: (1) Providing problems to students, (2) Grouping students to solve problems, (3) Assisting independent and group investigations, (4) Develop, present and present the work, (5) Analyze and analyze problems (Arends, 2008: 57). The characteristics of the problembased learning model are (1) The emergence of questions or problems from students, (2) Focus on interdisciplinary relationships, (3) Authentic investigations, (4) Producing products or works and presenting in front of the class, and (4) Increase cooperation between students (Trianto, 2009: 93). This study was conducted to determine the effect of the Problem Based Learning (PBL) learning model on learning outcomes in the subjects of the basics of building construction and land measurement techniques for 
vocational high school students. The benefit of this research is to provide new knowledge for DPIB (Modeling Design and Building Information) teachers to vary deep learning models, as well as foster developing student potential and intelligence as factors that affect student learning outcomes in schools.

\section{LITERATURE REVIEW}

\section{Problem Based Learning}

The Problem Based Learning (PBL) learning model is a learning model that involves students in solving a problem through several stages so that students are expected to be able to learn the subject matter as well as have skills in problem solving (Kamdi, 2007: 77). According to Sani (2014: 127) explains that Problem Based Learning (PBL) is a learning model that is carried out by giving a problem, asking questions, facilitating investigations and having mutual dialogue. According to Hosnan (2014: 294) states that Problem Based Learning is a learning model with a student learning approach to authentic problems so that students can compile their own knowledge, develop higher skills, and inquiry, independent students and increase selfconfidence. Problem Based Learning has five phases in learning which are described in Table 2.1.

Table 1. Sintaks Problem Based Learning

\begin{tabular}{cll}
\hline No. & \multicolumn{1}{c}{ Phase } & \multicolumn{1}{c}{ Teacher Implementation } \\
\hline 1 & Orient students to & The teacher discusses the learning \\
& the problem & $\begin{array}{l}\text { objectives, explains the material needed, } \\
\text { motivates students to be involved in } \\
\text { solving the selected problem. Learning } \\
\end{array}$ \\
& & begins by explaining the learning \\
& & \\
& &
\end{tabular}

2 Organizing students The teacher divides students into groups to learn and helps students to organize learning tasks in each problem. The teacher can choose different problems for each group but with the same level of difficulty. The principle in forming groups is that groups must be heterogeneous, interaction between group members, active discussion and peer tutors.

3 Guiding group investigations

$4 \quad$ Develop and present the work

\begin{tabular}{cll}
\hline No. & \multicolumn{1}{c}{ Phase } & \multicolumn{1}{c}{ Teacher Implementation } \\
\hline 5 & $\begin{array}{l}\text { Analyze and } \\
\text { evaluate the } \\
\text { problem-solving } \\
\text { process }\end{array}$ & $\begin{array}{l}\text { The teacher helps students reflect and } \\
\text { evaluate student investigations and the } \\
\text { processes used. This phase is the final } \\
\text { stage in PBL which is intended to help } \\
\text { students analyze and evaluate the } \\
\end{array}$ \\
& $\begin{array}{l}\text { processes, inquiry skills, and } \\
\text { intellectuals used. }\end{array}$
\end{tabular}

Source: (Nur, 2011).

Problem Based Learning in this study is a studentcentered learning model in presenting problems, questions, investigations and discussions between teachers and students on the basic competencies of specifications, characteristics and concrete construction procedures where the teacher acts as a facilitator so as to stimulate students to learn to solve problems.

\section{Learning Outcomes}

Learning outcomes are patterns of actions, values, understandings, attitudes, appreciation, and skills. Learning outcomes refer to learning achievement that is an indicator of the existence and degree of change in student behavior (Suprijono, 2009: 5). Meanwhile, according to Fitri (2014: 19) states that learning outcomes are an educational assessment of student progress in all things learned in school regarding the knowledge, skills or skills that are stated after the assessment.

According to Muhibbin (2010: 145) explains that in general the factors that affect learning outcomes can be divided into three types as follows:

a. Internal Factor, namely the physical and spiritual condition of the students.

b. Eksternal Factor, namely environmental conditions around students.

c. The Learning approach factor, namely the type of student learning efforts that include models, strategies and learning models used by the teacher in delivering material.

Based on the above definitions, it can be concluded that learning outcomes are the results of learning activities which are indicated by numbers to show the achievement of the learning process.

\section{Subjects on Fundamentals of Building Construction and Land Measurement Techniques}

The subject of basic building construction and land measurement techniques is one of the subjects given to class $\mathrm{X}$ students in the field of building modeling and information design (DPIB) expertise. The subject matter of the basics of building construction and land measurement techniques is divided into 2 parts, where one semester discusses the basics of building construction and the next semester discusses land measurement techniques. 


\section{METHODS}

This research was conducted through a literature review of relevant references and research results and continued through a focus group discussion (FGD). The relevant references include the policies of the Government of the Republic of Indonesia, and books on vocational and vocational education. Meanwhile, a study of relevant research results is a study of related research results. Based on the results of this study, data analysis techniques were carried out using descriptive-qualitative techniques (Sugiyono: 2006).

\section{RESULTS AND DISCUSSIONS}

There are a number of research results on the effect of problem based learning models on learning outcomes of vocational school students. Luh Ayu, Nancy \& Budi (2018), the conclusion of this study is that problem based learning improves the cognitive of each student so as to produce students who are independent and have thinking skills.

Research by Melanie, Elizabeth \& Courtney (2017) entitled "Problem based learning (PBL) and student interest in STEM careers: the roles of motivation and ability beliefs". The results of this study indicate that there is a relationship between PBL and students' interest in STEM in the future. Anna \& Husamah's research (2018) entitled "Problem based learning: creative thinking skills, problem solving skills, and learning outcomes of seventh grade students". The conclusions of this study indicate that the application of PBL improves (1) the average creative thinking skills are $11 \%$ and the completion rate is $17.5 \%$; (2) the average knowledge of problem solving skills is $27 \%$ and $47 \%$ completion; and (3) the average score of learning outcomes is $3 \%$ and the completion rate is $15 \%$. PBL can be implemented by teachers to improve students' creative thinking skills, problem-solving skills, and learning outcomes.

Lan Yu \& Sirinthorn's research (2015) entitled "Problem based learning materials design for a medical English course". The conclusion of this study is that the PBL material design for medical English courses provides a deeper understanding of the content material design process, which consists of defining the context, designing PBL material and several sub-steps. Rahmat's research (2020) entitled "Implementation of Problem Based Learning Model Assisted by E-Modules on Students Critical Thinking Ability". It can be concluded that the Problem Based Learning (PBL) model can be implemented very well because the problems discussed in the learning process are not new, the teacher has explained how the learning process will be carried out, students are used to learning in groups, as well as a learning environment and a supportive community. . Problem Based Learning (PBL) learning model, if implemented properly following the stages, can improve students' critical thinking skills, especially on the indicator "Developing strategies and tactics".

In addition, the problem based learning model has several advantages, as expressed by Wulandari, Bekti (2013) states that the advantages are as follows: (a) problem solving in PBL is good enough to understand the content of the lesson; (b) problem solving takes place during the learning process to challenge students' abilities and provide satisfaction to students; (c) PBL can increase learning activities; (d) assisting the transfer process of students to understand problems in everyday life; (e) helping students develop their knowledge and helping students to take responsibility for their own learning; (f) helping students to understand the essence of learning as a way of thinking, not just understanding learning by teachers based on textbooks; (g) PBL creates a learning environment that is fun and preferred by students; (h) enable applications in the real world; and (i) stimulate students to learn continuously.

Regarding implementation, Sulistyani, Niluh (2018) revealed that there is a match between theory and implementation of the learning model. The PBL model consists of the following stages: 1) providing an orientation about problems to students, 2) organizing students, 3) assisting independent and group investigations, 4) developing and presenting artifacts and exhibits, and 5) analyzing and evaluating well-applied processes.

\section{CONCLUSIONS}

Based on a review of the literature and relevant research results, and reviewed with a focus group discussion (FGD), the following conclusions were obtained: (a) Problem Based Learning in this study is a student-centered learning model in presenting problems, questions, and investigations. and discussions between teachers and students on basic competency specifications, characteristics and procedures for concrete construction where the teacher acts as a facilitator so as to stimulate students to learn to solve problems; (b) students' learning outcomes of basic programming can be improved through the application of problem-based learning models; (c) In addition to improving student learning outcomes, the application of problem-based learning models in the learning process can also increase students' self-confidence and can hone their collaborative skills; (d) there is a significant positive influence between the variable problem based learning model and student learning outcomes, which means that student learning outcomes can be improved through the application of problem based learning models.

\section{Acknowledgement}

The authors would like to thanks the supervisors from Magister of Technology and Vocational Education, State 
University of Surabaya for their assistance in the completed this study.

\section{Author's Contributions}

All authors discussed the results and contributed to from the start to final manuscript.

\section{Conflict of Interest}

The authors declare that they have no competing interests.

\section{REFERENCES}

Anderseon, L. W. \& Krathwohl, D. R. (2010). Pembelajaran, pengajaran dan asesmen. (Agung Prihantoro Penerjemah). Yogyakarta: Pustaka Pelajar.

Arends, Richard. (2008). Learning to teach. (Heri Prajitno \& Sri Mulyani, Penerjemah). New York: McGraw Hill Company.

Arikunto, Suharsimi. (2009). Dasar-dasar evaluasi pendidikan. Jakarta: Budi Aksara.

Ayu, Luh \& Rehatta, Nancy. (2018). Identifying the successfulness of a problem based learning in an undergraduate medical education programme. The Indonesian Journal of Medicine, $7(3), 170-174$.

Azwar, S. 2012. Reliabilitas dan Validitas. Yogyakarta: Pustaka Pelajar.

Basuki, Ismet. (2015). Asesmen pembelajaran. Bandung: Remaja Rosdakarya.

Career Center Maine Department of Labor. (2004). Today's Work Competence in Maine. (Online),

http:/ / www.maine.gov/labor/Imis/pdf/EssentialWork Competencies.pdf.

Elaine. (2016). Problem based learning: an overview of its process and impact on learning. Health Professions Education, 1(2), doi: 10.1016/j.hpe.2016. 01.004.

Fitri, Dkk. 2014. Penerapan strategi the firing line Pada Pembelajaran Matematika Siswa Kelas XI IPS SMA Negeri 1 Batipuh. Jurnal Pendidikan Matematika.3(1)

Hamalik, Oemar. (2004), Proses Belajar Mengajar. Jakarta: Bumi Aksara.

Hamzah. B. Uno. (2013). Teori Motivasi dan Pengukurannya. Jakarta: Bumi Aksara.

Hosnan, M. (2014). Pendekatan saintifik dan kontekstual dalam pembelajaran abad 21. Bogor: Ghalia Indonesia.

Jurrotul, Anna \& Husamah. (2018). Problem based learning:creative thinking skills, problem solving skills, and learning outcome of seventh grade students. Indonesian Journal of Biology Education, 4(2), ISSN: $2527-$ 6204.

Kamdi, W. (2007). Model-model pembelajaran inovatif. Malang: Universitas Negeri Malang.

Kerlinger, Fred N. (1973). Fundations of behavioral research: educational and psychological enquiry. New York: Holt, Rinehalt and Winsto Inc.
Lan, Yu. (2015). Problem based learning materials design for a medical English course. Theory and Practice in Language Studies, 5(7), http:/ / dx.doi.org/10.17507/tpls.0507.05

Melanie \& Noble, Elizabeth. (2017). Problem based learning (PBL) and student interest in STEM careers: the roles of motivation and ability beliefs. Education Science, 7(92), doi:103390/educsci7040092.

Muhibbin, Syah. (2010). Psikologi belajar. Jakarta: Rajawali Pers.

Nur, Mohamad. (2011). Model pembelajaran berdasarkan masalah. Surabaya: Unesa University Press.

Nur, Mohamad. (2011). Model pengajaran langsung. Surabaya: Unesa University Press.

Nur, Mohamad. (2011). Pemotivasian siswa untuk belajar.Surabaya: Unesa.

Purwanto. (2007). Psikologi pendidikan. Bandung: PT Remaja Rosdakarya.

Purwanto. (2010). Evaluasi hasil belajar. Bandung: Pustaka Pelajar.

Rahmat. (2020). Implementation of Problem Based Learning Model Assisted by E-Modules on Students Critical Thinking Ability. JPI, 9(3) September 2020. Doi: 10.23887/jpiundiksha.v9i3.22410

Riduwan. (2015). Skala pengukuran variable-variabel penelitian. Bandung: Alfabeta.

Sani, A. (2014). Pembelajaran saintifik untuk implementasi kurikulum 2013. Jakarta: Bumi Aksara.

Sanjaya, W. (2006). Strategi pembelajaran. Jakarta: Kencana Prenada Media Group.

Sardiman. (2007). Interaksi dan motivasi belajar mengajar. Bandung: Rajawali Pers.

Sulistyani, Niluh. (2018). Implementation of Problem Based Learning Model (PBL) Based on Reflective Pedagogy Aproach on Advanced Statistics Learning. IJIET, 2(1).

Sugiyono. (2013). Metode penelitian pendidikan pendekatan kuantitatif, kualitatif, dan R\&D. Bandung: Alfabeta.

Sugiyono. (2011). Statistika untuk penelitian. Bandung: Alfabeta.

Suprijono, Agus. (2009). Cooperative Learnnig Teori \& Aplikasi PAIKEM. Yogyakarta:Pustaka Belajar.

Suyono. (2014). Belajar dan pembelajaran. Bandung: Remaja Rosdakarya.

Tuckman. (1999). Conduting educational research ( $\left.5^{\text {th }} E d\right)$. Orlondo, FL: Harcourt Brance.

Trianto. (2009). Mendesain model pembelajaran inovatif-progresif. Surabaya: Kencana Prenada Media Group.

Widoyoko, E. P. (2014). Penilaian hasil pembelajaran di sekolah. Yogyakarta: Pustaka Pelajar.

Wulandari, Bekti. (2013). Pengaruh Problem Based Learning Terhadap Hasil Belajar Ditinjau Dari Motivasi Belajar PLC di SMK. Jurnal Pendidikan Vokasi, 3(2), Juni 2013. 